\title{
The performance of gold-mouth turban Turbo chrysostomus larvae in different temperature and salinity media
}

\section{Kinerja larva siput mata bulan Turbo chrysostomus pada suhu dan salinitas media yang berbeda}

\author{
Aris Sando Hamzah ${ }^{1 *}$, Kukuh Nirmala ${ }^{1}$, Eddy Supriyono ${ }^{1}$, Irzal Effendi', \\ Sigit A.P. Dwiono ${ }^{2}$ \\ 'Department of Aquaculture, Faculty of Fisheries and Marine Science, IPB University, \\ Bogor, West Java, Indonesia \\ ${ }^{2}$ Central Marine Bio Industry, Indonesian Institute of Sciences (LIPI), Mataram, West Nusa Tenggara, Indonesia \\ *Corresponding author: arissandohamzah@gmail.com
}

(Received September 22, 2020; Accepted October 16, 2020)

\begin{abstract}
This study aimed to evaluate the effect of temperature and salinity on the development, growth, and survival rate of gold-mouth turban T. chrysostomus larvae. The temperature was adjusted by heater and salinity was by the freshwater dilution. The temperature treatments were $\mathrm{A} 1\left(27 \pm 0.5^{\circ} \mathrm{C}\right)$ and $\mathrm{A} 2\left(30 \pm 0.5^{\circ} \mathrm{C}\right)$, while the salinity treatments were B1 $(29 \pm 0.5 \mathrm{~g} / \mathrm{L}), \mathrm{B} 2(32 \pm 0.5 \mathrm{~g} / \mathrm{L})$, and B3 $(35 \pm 0.5 \mathrm{~g} / \mathrm{L})$. These treatments were repeated three times. The results showed that the pre-torsion veliger stage was formed at about 11 hours 36 minutes after fertilization or at about 3 hours after the trocophor stage. The A1B3 treatment obtained the fastest early post-torsion veliger and late post-torsion veliger stage period after fertilization. Temperature had no significant effect, while salinity had a significant effect in the specific growth rate of gold-mouth turban larvae. The highest specific growth rate at $27 \pm 0.5^{\circ} \mathrm{C}$ (A1) was obtained in the $\mathrm{B} 3$ treatment and insignificantly different from the $\mathrm{B} 2$ treatment. Temperature and salinity had a significant effect, but the interaction between these factors had no significant effect in the survival rate of gold-mouth turban larvae. The A1B3 treatment obtained the highest percentage of survival rate and was significantly different from the $\mathrm{A} 1 \mathrm{~B} 2$ treatment. The optimum temperature and salinity ranges for maintaining the gold-mouth turban larvae are $26.5-27.5^{\circ} \mathrm{C}$ and $31.5-35.5 \mathrm{~g} / \mathrm{L}$, respectively. The water quality parameters obtained could still support the larvae development until the juvenile stage.
\end{abstract}

Keywords: temperature, salinity, larvae, gold-mouth turban

\begin{abstract}
ABSTRAK
Tujuan penelitian ini yaitu mengevaluasi pengaruh suhu dan salinitas terhadap perkembangan, pertumbuhan, dan kelangsungan hidup larva siput mata bulan T. chrysostomus. Suhu diatur menggunakan heater dan salinitas dengan melakukan pengenceran air tawar. Perlakuan suhu yaitu $\mathrm{A} 1\left(27 \pm 0.5^{\circ} \mathrm{C}\right)$ dan $\mathrm{A} 2\left(30 \pm 0.5^{\circ} \mathrm{C}\right)$, sementara salinitas yaitu B1 $(29 \pm 0.5 \mathrm{~g} / \mathrm{L}), \mathrm{B} 2(32 \pm 0.5 \mathrm{~g} / \mathrm{L})$ dan B3 $(35 \pm 0.5 \mathrm{~g} / \mathrm{L})$ diulang sebanyak 3 kali. Hasil pengamatan menunjukan bahwa stadia veliger pra-torsi dicapai sekitar 11 jam 36 menit setelah fertilisasi atau sekitar 3 jam setelah trocophor. Perlakuan A1B3 memberikan waktu pencapaian stadia veliger pasca-torsi awal dan veliger pasca-torsi akhir tercepat setelah pembuahan. Suhu tidak berpengaruh nyata sedangkan salinitas berpengaruh nyata terhadap laju pertumbuhan harian larva siput mata bulan. Laju pertumbuhan harian tertinggi pada suhu perlakuan A1 didapatkan pada perlakuan B3 dan menunjukan nilai tidak berbeda nyata dengan perlakuan B2. Suhu dan salinitas memberikan pengaruh signifikan, tetapi interaksi keduanya tidak menunjukan pengaruh yang signifikan terhadap tingkat kelangsungan hidup larva siput mata bulan. Perlakuan A1B3 memberikan persentase tingkat kelangsungan hidup tertinggi dan tidak menunjukan nilai yang berbeda nyata dengan perlakuan A1B2. Kisaran suhu dan salinitas optimum bagi pemeliharaan larva siput mata bulan yaitu suhu $26.5-27.5^{\circ} \mathrm{C}$ dan salinitas 31.5-35.5 g/L. Parameter kualitas air yang diperoleh masih mendukung perkembangan larva siput mata bulan hingga mencapai stadia juvenil.
\end{abstract}

Kata kunci: suhu, salinitas, larva, siput mata bulan 


\section{INTRODUCTION}

The gold-mouth turban Turbo chrysostomus is a quite potential invertebral spesies due to easier maintenance and having a good survival ability against the environmental changes (Setyono et al., 2013). Gold-mouth turban can be found in the Indo-Pacific, South-East Asia, Fiji Islands coastal regions. This snail species can also be found in the Ryukyu Islands, Japan coastal region and Northern Melanesia to Southern New Caledonia water areas (Soekendarsi, 2018). Gold-mouth turban often becomes the local community target, due to the savory taste and high nutrient contents. The gold-mouth turban also becomes a popular aquarium organism. Based on this condition, gold-mouth turban (T. chrysostomus) has been rarely found in the Indonesian water areas (Ubaidillah et al., 2013). Ruf (2007) also added that the fairly high price of the carved shells around IDR 258,000 (US \$ 18) per kg is thought to likely occur due to the drastic decline of these organisms in Sabah water area. Moreover, the coral reef damage and environmental change are also thought to be the main factors of the declined population in nature (Seinor et al., 2020).

Culture can become a solution to overcome these problems. However, the current gold-mouth turban (T. chrysostomus) culture in Indonesia has not been commercially performed due to less information about the culture process, specifically in the breeding stage. The larval phase often occurs a high mortality, either in the early development (veliger) to the larval final development. The larvae phase is a transitional period, as mishandling and water condition changes can lead to a mortality that directly impacts the seed quantity and quality produced. Temperature and salinity are the water quality parameters that play the important roles in supporting the gold-mouth turban breeding activity. The optimum temperature can induce the larval appetite, which implicates in the larval performance. Meanwhile, the extreme temperature can interfere with the physiological response of larvae and cause a high mortality (Huo et al., 2017). In the juvenile phase, goldmouth turban is also influenced by temperature, which tended to grow faster at $26 \pm 0.5^{\circ} \mathrm{C}$ and were thought to be associated with the high daily feed intake (Hamzah, 2015).

The salinity change can cause the increased energy demand, especially in balancing the osmotic pressure between body and environment, which impacts on the energy sharing. The higher total energy used to balnce the osmotic pressure, the less reserved energy utilized for growth, movement, and other biological requirements (Amin et al., 2016). The giant abalone Haliotis gigantean can adapt to low salinity in a long period and produce higher survival rate than the disc abalone ( $H$. discus discus) (Manuel et al., 2019). Morash and Alter (2015) stated that larvae are more easily exposed to diseases due to temperature and salinity fluctuations. Both parameters can influence the body immune system. The optimum temperature and sainity interactions in the pearl oyster larvae obtained the highest survival and growth rates by improving the protease enzyme activity and a higher $\mathrm{CaCO}_{3}$ content than the other treatments (Hamzah et al., 2016b). Lah et al. (2016) stated that the biotic factors and environmental conditions, namely, temperature and salinity can also influence the marine organism fatty acid composition.

The gold-mouth turban breeding often fails due to the water quality change. Temperature and salinity can cause egg and larvae abnormalities, inhibited larvae development, and mortality. High mortality occurs whenever during the metamorphosis stage; therefore, the fluctuative temperature and salinity in the maintenance media extremely influence the gold-mouth turban production (Kimani, 1996; Setyono et al., 2013). This study aimed to evaluate the effect of temperature and salinity on the development, growth, and survival rate of gold-mouth turban $T$. chrysostomus larvae.

\section{MATERIALS AND METHOD}

\section{Experimental design}

This study contained two temperature levels and three salinity levels. The temperature treatments were A1 $\left(27 \pm 0.5^{\circ} \mathrm{C}\right)$ and $\mathrm{A} 2(30 \pm$ $\left.0.5^{\circ} \mathrm{C}\right)$, while the salinity treatments were $\mathrm{B} 1$ $(29 \pm 0.5 \mathrm{~g} / \mathrm{L}), \mathrm{B} 2(32 \pm 0.5 \mathrm{~g} / \mathrm{L})$, and B3 (35 \pm $0.5 \mathrm{~g} / \mathrm{L}$ ), which were repeated three times. The maintenance tank contained 18 units of containers which were randomly distributed. The container tanks used were made of white colored plastic at $73 \times 52 \times 42 \mathrm{~cm}(\mathrm{P} \times \mathrm{L} \times \mathrm{T})$ volume.

\section{Procedures \\ Tank preparation}

The preparatory step began by sanding the maintenance container and plate (larval attachment medium) until quitely coarse. This aimed to facilitate the Navicula sp. attachment as 
a live feed. The plate used was white colored fiber media at $25 \times 20 \mathrm{~cm}(\mathrm{P} \times \mathrm{L})$ size. After sanding, the maintenance container and plate were cleaned until sterilized and dried. Three plate units were hung in each maintenance container, and the container was filled with the sterilized marinewater.

The live feed was proliferated at about 2 weeks before larval stocking by growing Navicula sp. in the larval attachment media. The live feed grown in the attachment media were cultured by administering $1 \mathrm{~mL} / \mathrm{L}$ of KW21 liquid fertilizer type equipped with a $15 \mathrm{~W}$ lamp to stimulate these diatom growth. KW21 fertilizer is a commercial fertilizer containing $49 \mathrm{~g} / \mathrm{L}$ nitrogen $(\mathrm{N}), 4 \mathrm{~g} / \mathrm{L}$ phosphoric acid $(\mathrm{P})$, boron, manganese, iron, zinc, cobalt, EDTA, amino acid complex, and vitamins (Mukhlis et al., 2017). For maintaining the live feed availability in the experimental media, the live feed was provided at 20000 cells after water exchange.

The spawning technique was modified from the methods developed by Setyono et al. (2013), whereas the shell-cleaned snails were distributed into a $20 \mathrm{~L}$ plastic container equipped with strong aeration for 30 minutes. Snails were induced with desiccation method by remaining the broodstock without water for 15 minutes as a low-tide artificial method. Broodstocks containing 16 females and 22 males were distributed into the maintenance tank equipped with small aeration and remained unfed. Spawning occurred at about 19.30 $(\mathrm{GMT}+8)$ as male broodstock initially released clear colored spermatozoa, followed by female broodstock, which released green colored eggs. After broodstock spawning, eggs were filtered and reared to reach pre-torsion veliger stadia. After reaching the pre-torsion veliger stadia, larvae were reared in the maintenance container at 10000 larvae/60 L water stocking density.

\section{Water and treatment preparations}

Marinewater was sterilized from the water tower and flown to the maintenance container through the UV equipped with a filter bag at the end of the hose. By performing this treatment, the water media used for the experimental animal maintenance was clean and away from dirts and particles that can interfere the larvae life.

The maintenance containers were maintained in the temperature and salinity treatments for 20 days. The maintenance containers maintained at 27 $\pm 0.5^{\circ} \mathrm{C}$ and $30 \pm 0.5^{\circ} \mathrm{C}$ treatments were set using a heater by regulating it based on the treatments provided. The marinewater obtained had $35 \mathrm{~g} / \mathrm{L}$ salinity; therefore, to maintain the salinity at $32 \pm$ $0.5 \mathrm{~g} / \mathrm{L}$ and $29 \pm 0.5 \mathrm{~g} / \mathrm{L}$ treatments, dilution was performed by adding the freshwater. The dilution procedure was referred to Winanto et al. (2009):

$$
\mathrm{S}=\frac{(\mathrm{S} 1 \times \mathrm{V} 1)+(\mathrm{S} 2 \times \mathrm{V} 2)}{\mathrm{V} 1+\mathrm{V} 2}
$$

Note:

$\mathrm{S} \quad=$ maintained salinity $(\mathrm{g} / \mathrm{L})$

$\mathrm{S} 1=$ marinewater salinity $(\mathrm{g} / \mathrm{L})$

$\mathrm{S} 2=$ freshwater salinity $(\mathrm{g} / \mathrm{L})$

$\mathrm{V} 1=$ marinewater volume $(\mathrm{L})$

V2 = freshwater volume $(\mathrm{L})$

The water quality parameters in the experimental media, mainly temperature and salinity, were monitored gradually twice a day. Moreover, to maintain the experimental water quality media, water exchange was totally performed $(100 \%)$ three times a day.

\section{Parameters}

Stadia development

The larvae stadia development was presented descriptively by showing the shell length and stadium achievement period. The gold-mouth turban snail larvae length measurement was modified from Noble et al. (2015) (Figure 1).

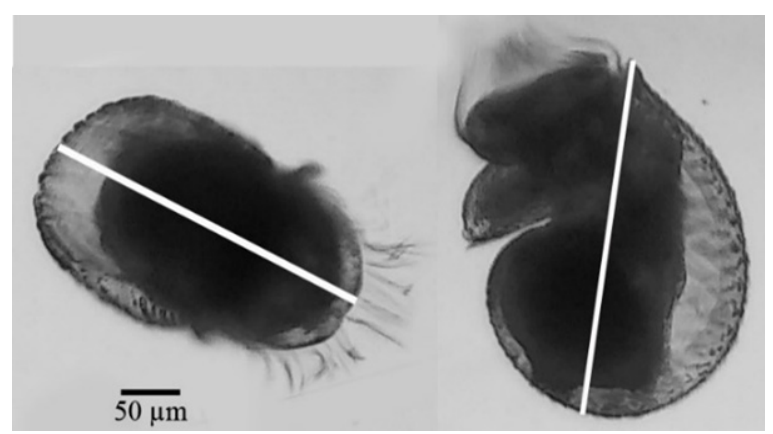

Figure 1. Gold-mouth turban shell length measurement

The stadium achievement period can be defined as the requirement period for larvae to reach one developmental stadium. The larvae achievement period analysis referred to McCormick et al. (2016) method through identification, total larvae calculation in each stadium, and larvae required period calculation to reach the stadium.

\section{Larval attachment capability (LA)}

The larval attachment capability was calculated in 2 days (48 hours) and 3 days (72 hours) after fertilization. The larval attachment capability was calculated with the formula of Yu et al. (2020), namely: 


$$
\mathrm{AC}=\frac{\mathrm{N}_{\mathrm{p}}}{\mathrm{N}_{\mathrm{t}}} \times 100
$$

Note:

$\mathrm{AC}=$ larval attachment capability $(\%)$

$\mathrm{NP}=$ total attached larvae on the plate (individual)

$\mathrm{Nt}=$ total larvae on the plate and water column (individual)

Specific growth rate

The specific growth rate of gold-mouth turban larvae was calculated using the formula of Noble et al. (2015), namely:

$$
\mathrm{SGR}=\frac{(\mathrm{Ln} \mathrm{L} 1-\mathrm{Ln} \mathrm{L} 0)}{\mathrm{T}} \times 100
$$

Note:

$\mathrm{SGR}=$ specific growth rate $(\% /$ day $)$

L1 = shell length at the final observation $(\mu \mathrm{m})$

L0 = shell length at the initial observation $(\mu \mathrm{m})$
$\mathrm{T}=$ observational period (day)

Ln = natural logarithm

\section{Survival rate}

The survival rate of gold-mouth turban larvae was calculated by using the formula of Hamzah et al. (2016a), namely:

$$
\mathrm{SR}=\frac{\mathrm{N}_{\mathrm{t}}}{\mathrm{N}_{0}} \times 100
$$

Note:

$\mathrm{SR}=$ survival rate $(\%)$

$\mathrm{Nt} \quad=$ total final juvenile (individual)

No $=$ total initial juvenile (individual)

\section{Water quality}

The water quality parameters, namely, salinity, temperature, $\mathrm{pH}$, and DO were measured before and after the water exchange, while phosphate, nitrate, and nitrite contents were performed in the initial and final maintenance period.

Table 1. Gold-mouth turban larvae shell length in various stadia (mean $\pm \mathrm{SD})$

\begin{tabular}{ccccccc}
\hline \multirow{2}{*}{ Stadia } & \multicolumn{7}{c}{ Shell length $(\mu \mathrm{m})$} \\
\cline { 2 - 7 } & A1B1 & A1B2 & A1B3 & A2B1 & A2B2 & A2B3 \\
\hline V1 & $250.20 \pm 28.52$ & $250.24 \pm 28.52$ & $250.24 \pm 28.52$ & $250.24 \pm 28.52$ & $250.24 \pm 28.52$ & $250.24 \pm 28.52$ \\
V2 & $257.57 \pm 27.14$ & $266.50 \pm 28.93$ & $269.11 \pm 34.81$ & $256.52 \pm 30.21$ & $266.39 \pm 36.57$ & $267.31 \pm 33.90$ \\
V3 & $263.39 \pm 29.18$ & $280.04 \pm 28.74$ & $280.87 \pm 33.16$ & $261.96 \pm 26.46$ & $278.27 \pm 27.33$ & $278.89 \pm 29.65$ \\
\hline
\end{tabular}

Note: $\mathrm{A} 1 \mathrm{~B} 1=27 \pm 0.5^{\circ} \mathrm{C}$ and $29 \pm 0.5 \mathrm{~g} / \mathrm{L}, \mathrm{A} 1 \mathrm{~B} 2=27 \pm 0.5^{\circ} \mathrm{C}$ and $32 \pm 0.5 \mathrm{~g} / \mathrm{L}, \mathrm{A} 1 \mathrm{~B} 3=27 \pm 0.5^{\circ} \mathrm{C}$ and $35 \pm 0.5$ $\mathrm{g} / \mathrm{L}, \mathrm{A} 2 \mathrm{~B} 1=30 \pm 0.5^{\circ} \mathrm{C}$ and $29 \pm 0.5 \mathrm{~g} / \mathrm{L}, \mathrm{A} 2 \mathrm{~B} 2=30 \pm 0.5^{\circ} \mathrm{C}$ and $32 \pm 0.5 \mathrm{~g} / \mathrm{L}, \mathrm{A} 2 \mathrm{~B} 3=30 \pm 0.5^{\circ} \mathrm{C}$ and $35 \pm 0.5$

\begin{tabular}{|c|c|c|c|c|c|c|}
\hline \multirow{2}{*}{ Development } & \multicolumn{6}{|c|}{ Period (hour.minute) } \\
\hline & A1B1 & A1B2 & A1B3 & $\mathrm{A} 2 \mathrm{~B} 1$ & $\mathrm{~A} 2 \mathrm{~B} 2$ & A2B3 \\
\hline Pre-torsion veliger & 11.36 & 11.36 & 11.36 & 11.36 & 11.36 & 11.36 \\
\hline Visible cilia & 11.36 & 11.36 & 11.36 & 11.36 & 11.36 & 11.36 \\
\hline Covering shell & 14.46 & 14.35 & 14.23 & 14.40 & 14.36 & 14.30 \\
\hline Developed Feet clumps & 14.46 & 14.35 & 14.23 & 14.40 & 14.36 & 14.30 \\
\hline Visible retractor muscle & 14.46 & 14.35 & 14.23 & 14.40 & 14.36 & 14.30 \\
\hline Eye-spot & 16.46 & 16.36 & 16.23 & 16.40 & 16.36 & 16.30 \\
\hline Early post-torsion veliger & 20.30 & 19.49 & 19.36 & 20.28 & 19.50 & 19.40 \\
\hline Perfectly-formed shell & 20.30 & 19.49 & 19.36 & 20.28 & 19.50 & 19.40 \\
\hline Late post-torsion veliger & 23.25 & 22.48 & 22.36 & 23.20 & 22.54 & 22.50 \\
\hline Operculum & 26.56 & 26.19 & 26.07 & 26.51 & 26.25 & 26.21 \\
\hline Formed feet & 28.25 & 27.48 & 27.36 & 28.20 & 27.54 & 27.50 \\
\hline Visible propodium & 36.55 & 36.18 & 36.06 & 36.50 & 36.24 & 36.20 \\
\hline
\end{tabular}
$\mathrm{g} / \mathrm{L}$, pre-torsion veliger stage (V1), early post-torsion veliger stage (V2), and late post-torsion veliger stage (V3).

Table 2. Gold-mouth larvae stadia development

Note: $\mathrm{A} 1 \mathrm{~B} 1=27 \pm 0.5^{\circ} \mathrm{C}$ and $29 \pm 0.5 \mathrm{~g} / \mathrm{L}, \mathrm{A} 1 \mathrm{~B} 2=27 \pm 0.5^{\circ} \mathrm{C}$ and $32 \pm 0.5 \mathrm{~g} / \mathrm{L}, \mathrm{A} 1 \mathrm{~B} 3=27 \pm 0.5^{\circ} \mathrm{C}$ and $35 \pm$ $0.5 \mathrm{~g} / \mathrm{L}, \mathrm{A} 2 \mathrm{~B} 1=30 \pm 0.5^{\circ} \mathrm{C}$ and $29 \pm 0.5 \mathrm{~g} / \mathrm{L}, \mathrm{A} 2 \mathrm{~B} 2=30 \pm 0.5^{\circ} \mathrm{C}$ and $32 \pm 0.5 \mathrm{~g} / \mathrm{L}, \mathrm{A} 2 \mathrm{~B} 3=30 \pm 0.5^{\circ} \mathrm{C}$ and 35 $\pm 0.5 \mathrm{~g} / \mathrm{L}$. 


\section{Data analysis}

The growth, larval attachment capability, and survival rate data were analyzed with an analysis of variance (ANOVA), while the stadia development and water quality data were analyzed descriptively. The data analysis was assisted by IBM SPSS Statistics 23.0 software program.

\section{RESULTS AND DISCUSSION}

\section{Results}

\section{Larval development}

The observational results of shell length and stadium achievement period in the gold-mouth turban are presented in Table 1 and Table 2, respectively.

\section{Larval attachment capability and survival rate}

The ANOVA results showed that temperature and salinity significantly $(\mathrm{P}<0.05)$ influenced the attachment capability and survival rate of goldmouth turban larvae, therefore the data analysis were continued with the Duncan's test (Table 3).

\section{Specific growth rate}

The analysis of variance results showed that temperature insignificantly $(\mathrm{P}>0.05)$ influenced the specific growth rate of gold-mouth turban larvae, while the salinity treatments showed a significant influence in the specific growth rate of gold-mouth turban larvae, therefore the data analysis was continued with Duncan's test (Figure 2).

\section{Water quality}

The water quality conditions obtained during the study containing $\mathrm{pH}, \mathrm{DO}$, phosphate, nitrate, and nitrite are presented in Table 4.

Table 4. Water quality parameters during the goldmouth turban maintenance period at different temperatures and salinities

\begin{tabular}{cc}
\hline Parameter & Result \\
\hline $\mathrm{pH}$ & $7.70-8.20$ \\
$\mathrm{DO}(\mathrm{mg} / \mathrm{L})$ & $4.10-4.90$ \\
Fosphate $(\mathrm{mg} / \mathrm{L})$ & $0.13-0.50$ \\
Nitrate $(\mathrm{mg} / \mathrm{L})$ & $0.081-0.635$ \\
Nitrite $(\mathrm{mg} / \mathrm{L})$ & $0.001-0.035$ \\
\hline
\end{tabular}

Table 3. The attachment capability (AC) and survival rate (SR) of gold-mouth turban larvae (mean $\pm \mathrm{SB})$.

\begin{tabular}{ccccccc}
\hline \multirow{2}{*}{ Parameter } & \multicolumn{5}{c}{ Treatment } \\
\cline { 2 - 7 } & A1B1 & A1B2 & A1B3 & A2B1 & A2B2 & A2B3 \\
\hline AC 48 (\%) & $34.36 \pm 4.52^{\mathrm{b}}$ & $43.96 \pm 1.92^{\mathrm{c}}$ & $46.51 \pm 2.64^{\mathrm{c}}$ & $22.37 \pm 0.93^{\mathrm{a}}$ & $36.90 \pm 4.80^{\mathrm{b}}$ & $37.66 \pm 0.98^{\mathrm{b}}$ \\
AC 72 (\%) & $64.61 \pm 2.06^{\mathrm{b}}$ & $75.33 \pm 1.99^{\mathrm{d}}$ & $79.11 \pm 0.54^{\mathrm{d}}$ & $54.13 \pm 1.45^{\mathrm{a}}$ & $69.79 \pm 1.70^{\mathrm{c}}$ & $72.46 \pm 2.30^{\mathrm{c}}$ \\
SR (\%) & $4.42 \pm 0.41^{\mathrm{b}}$ & $5.38 \pm 0.13^{\mathrm{c}}$ & $5.39 \pm 0.20^{\mathrm{c}}$ & $3.38 \pm 0.42^{\mathrm{a}}$ & $4.70 \pm 0.21^{\mathrm{b}}$ & $4.82 \pm 0.13^{\mathrm{b}}$ \\
\hline
\end{tabular}

Note: $\mathrm{A} 1 \mathrm{~B} 1=27 \pm 0.5^{\circ} \mathrm{C}$ and $29 \pm 0.5 \mathrm{~g} / \mathrm{L}, \mathrm{A} 1 \mathrm{~B} 2=27 \pm 0.5^{\circ} \mathrm{C}$ and $32 \pm 0.5 \mathrm{~g} / \mathrm{L}, \mathrm{A} 1 \mathrm{~B} 3=27 \pm 0.5^{\circ} \mathrm{C}$ and $35 \pm$ $0.5 \mathrm{~g} / \mathrm{L}, \mathrm{A} 2 \mathrm{~B} 1=30 \pm 0.5^{\circ} \mathrm{C}$ and $29 \pm 0.5 \mathrm{~g} / \mathrm{L}, \mathrm{A} 2 \mathrm{~B} 2=30 \pm 0.5^{\circ} \mathrm{C}$ and $32 \pm 0.5 \mathrm{~g} / \mathrm{L}, \mathrm{A} 2 \mathrm{~B} 3=30 \pm 0.5^{\circ} \mathrm{C}$ and $35 \pm$ $0.5 \mathrm{~g} / \mathrm{L}, \mathrm{AC} 48=$ attachment capability in 48 hours, $\mathrm{AC} 72=$ attachment capability in 72 hours, $\mathrm{SR}=$ survival rate.

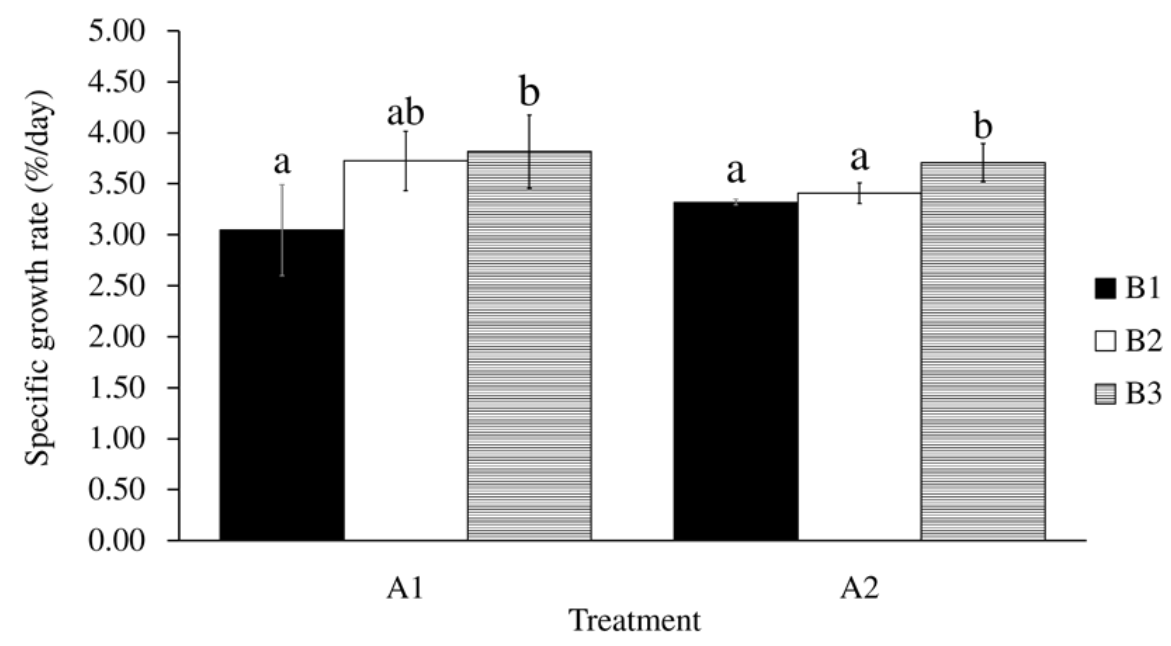

Figure 2. The specific growth rate (SGR) of gold-mouth turban larvae (Note: Different notations showed a significant difference value $(\mathrm{P}<0.05)) . \mathrm{A} 1=27 \pm 0.5^{\circ} \mathrm{C}, \mathrm{A} 2=30 \pm 0.5^{\circ} \mathrm{C}, \mathrm{B} 1=29 \pm 0.5 \mathrm{~g} / \mathrm{L}, \mathrm{B} 2=32 \pm 0.5 \mathrm{~g} / \mathrm{L}, \mathrm{B} 3=35 \pm 0.5 \mathrm{~g} / \mathrm{L}$. 


\section{Discussion}

The larvae development of gold-mouth turban was started from the pre-torsion veliger stadia, which achieved at about 11 hours 36 minutes after fertilization or 3 hours after trocophore stage. The results obtained were not quitely different from Setyono et al. (2013) as the early veliger stadia were achieved at about 11 hours 45 minutes after fertilization or 3 hours after the trocophore stage. In the pre-torsion veliger stadia, the shell covered all the soft organs, and the feet were initially developed with visible retractor muscles. The retractor muscles are functioned to move and pull the feet. Moreover, in these stadia, eye-spots were appeared as likely as small black spots. In the pearl oyster Pinctada maxima, these black spots indicate that the larvae will soon reach the pediveliger stage and be ready to attach (Hamzah et al., 2016a). The pre-torsion veliger larvae formed a shell at $250.24 \pm 28.52 \mu \mathrm{m}$ length and was visibly active to swim using cilia. The shell length of the gold-mouth turban larvae in the pretorsion veliger stage was smaller than the Turbo cornotus $(270 \pm 6 \mu \mathrm{m})$ and T. stenogyrus $(328$ $\pm 7 \mu \mathrm{m})$ (Kono \& Yamakawa, 2002), but larger than the T. argyrostomus, namely, 170-180 $\mu \mathrm{m}$ (Kimani, 1996).

In the early post-torsion veliger stadia, larvae formed a perfect shell shape. Yang et al. (2020) explained that during the torsion stage, the shell anterior and posterior parts will be reversed with the shell posterior end becomes the anterior part in the post-torsion veliger larvae stage. At the same period, the dorsal part will become the visceropallium gastric part. The early posttorsion veliger larvae are still lecitotrophic, which does not require feed from the outside and passively follows the water movement (Banne et al., 2017). Zamora et al. (2020) stated that the starfish Stegnaster inflatus eggs with $\sim 400 \mu \mathrm{m}$ diameter had a quite higher lipid content than the protein content at lipid:protein ratio of 0.96 . Approximately $80 \%$ egg proteins were used in the early larval stadia. Meanwhile, lipid was used to reach the early juvenile stage.

The observational results showed that the highest shell length during the post-torsion veliger stage was in the A1B3 at $269.11 \pm 34.81 \mu \mathrm{m}$, while the lowest shell length was in the A2B1 at $256.52 \pm 30.21 \mu \mathrm{m}$. This indicates that the 26.5$27.5^{\circ} \mathrm{C}$ temperature and $34.5-35.5 \mathrm{~g} / \mathrm{L}$ salinity was optimum to support the gold-mouth turban larval growth in the early post-torsion veliger stadia. This condition was similar to the Rapana venosa larvae which showed the highest at $25^{\circ} \mathrm{C}$ and $30 \mathrm{~g} / \mathrm{L}$ (Zhang et al., 2017). Rippington (2015) explained that low temperature, salinity, and live feed concentration caused the larvae not to grow or develop, and vice versa. This condition was thought due to associated with the larvae metabolism rate, which continuously increased along with the increased temperature at the optimum threshold of $28^{\circ} \mathrm{C}$ and decreased above the temperature threshold (Winanto et al., 2009).

In the late post-torsion veliger stadia, the larvae developed operculum, feet, and propodium. This condition was supported by Kimani (1996), that in the post-torsion veliger, small feet and operculum were visible at about 20-30 hours after fertilization. Operculum is functioned to protect the larvae from the predator attack. Larvae will enter the shell and spread in the base container (Peck et al., 2016). In the Nassarius reticulates, the feet are enlarged during the larval stadia, and the pigmented propodium appeared on the feet ventral proximal as becoming clearer in the metamorphosis stage (Zupo \& Patti, 2009). The veliger larvae still consume yellow-egg (endogenous feeding), therefore the feed provided, namely, Navicula sp. diatom, is utilized when the larvae are metamorphosized. The feeding behavior is similar to the turban snails, abalones, and several gastropods that utilize the yellowegg to achieve the pediveliger stadia (Noble et al., 2015; Mccormick et al., 2016; Banne et al., 2017).

The observational results showed that the highest larval shell length during the posttorsion veliger stadia was obtained from the A1B3 treatment at $280.87 \pm 33.16 \mu \mathrm{m}$, while the lowest shell length was obtained from the A2B1 treatment at $261.96 \pm 26.46 \mu \mathrm{m}$. This indicates that $26.5-27.5^{\circ} \mathrm{C}$ temperature and $34.5-35.5 \mathrm{~g} / \mathrm{L}$ salinity were optimum to support the shell length of gold-mouth turban in the late post-torsion veliger stadia. This condition was similar to the P. maxima larvae which showed the highest shell length at $28^{\circ} \mathrm{C}$ and $32-34 \mathrm{~g} / \mathrm{L}$ (Winanto et al., 2009). Nowland et al. (2019) also reported that the increased shell length of D-veliger larvae in 48 hours old was caused by the increased temperature and salinity that reached the optimum values, namely $32^{\circ} \mathrm{C}$ and $32 \mathrm{~g} / \mathrm{L}$.

The stadium achievement period is a duration required by larvae to reach one stadium development. The observational results showed that the A1B3 treatment obtained the fastest early and late post-torsion veliger stadia achievement 
at 19 hours 36 minutes and 22 hours 36 minutes after fertilization, respectively. Meanwhile, the A1B1 treatment obtained the slowest early and late post-torsion veliger stadia achievement at 20 hours 30 minutes and 23 hours 25 minutes after fertilization, respectively. This indicates that the $26.5-27.5^{\circ} \mathrm{C}$ temperature and $34.5-35.5$ $\mathrm{g} / \mathrm{L}$ salinity are the best condition to support the gold-mouth turban stadia achievement period. The similar condition also occurred in the pearl oyster ( $P$. maxima) which the fastest plantigrade stadia achievement period at $28^{\circ} \mathrm{C}$ and $32-34 \mathrm{~g} / \mathrm{L}$ (Winanto et al., 2009). Nowland et al. (2019) stated that the extreme temperature range $\left(<20^{\circ} \mathrm{C}\right)$ and salinity range $(<14$ and $>36 \mathrm{~g} / \mathrm{L})$ caused the larval stress to nearly dead by showing a pigment damage in the digestive system.

The larval attachment capability is ratio of the total attached larvae in the substrate and total numbers of larvae. The Duncan's test results showed that the A1B3 and A1B2 treatments at 48 and 72 hours had the best responses in the gold-mouth turban larvae attachment capability. Meanwhile, the A2B1 treatment obtained the worst response and had a significant different value compared to other treatments. This condition indicates that the $26.5-27.5^{\circ} \mathrm{C}$ temperature and $31.5-35.5 \mathrm{~g} / \mathrm{L}$ salinity are the optimum temperature and salinity ranges to support the gold-mouth turban larvae attachment capability. The results obtained were similar to the Tridacna gigas oyster larvae which achieved the fastest pediveliger larvae achievement in a higher salinity level at $34 \mathrm{~g} / \mathrm{L}(50 \pm 6.5 \%)$, and the slowest was obtained from $18 \mathrm{~g} / \mathrm{L}$ salinity $(24.1 \pm 6.4 \%)$ (Sayco et al., 2019). Montory et al. (2014) also reported that the Crepipatella peruviana veliger larvae could migrate to the water column from deeper water to find higher salinity (30-32 g/L) and prevent from low salinity level. The negative impact due to the environmental stressors during the metamorphosis period does not only influence the decreased shell length and lipid storage, but also having a continuous impact (Ko et al., 2014). In addition to salinity, temperature also plays an important role in the gold-mouth turban larvae attachment capability. The temperature range of 26.5-27.5 ${ }^{\circ} \mathrm{C}$ produced the highest percentage of attachment capability. The results obtained were similar to the Crassostrea gigas larvae which obtained the highest attachment capability at $27^{\circ} \mathrm{C}$ (Rico-Villa et al., 2009).

The A1B3 treatment obtained the highest survival rate (SR) and was significantly different from the A1B2 treatment $(\mathrm{P}>0.05)$. This condition indicates that the temperature range of $26.5-27.5^{\circ} \mathrm{C}$ and salinity range of $31.5-35.5 \mathrm{~g} / \mathrm{L}$ are the optimum temperature and salinity ranges in the gold-mouth turban larval maintenance. This condition was also similar to the pearl oyster $P$. maxima larvae which obtained the highest survival rate at $28^{\circ} \mathrm{C}$, and $32 \mathrm{~g} / \mathrm{L}$ and 34 $\mathrm{g} / \mathrm{L}$ salinities (Winanto et al., 2009). Tao and Qi (2018) reported that the oyster Crassostrea nippona juvenile obtained the highest survival rate along with the largest shell length at 25-30 $\mathrm{g} / \mathrm{L}$ salinity and $24-28^{\circ} \mathrm{C}$ temperature. In a nursery period, the gold-mouth turban has a quite high temperature tolerance among $25.5-28.5^{\circ} \mathrm{C}$ (Hamzah, 2015).

The lowest SR was obtained from the A2B1 treatment with insignificant difference among other treatments. This condition indicates that the combination of quite high temperature $\left(29.5-30.5^{\circ} \mathrm{C}\right)$ and low salinity $(28.5-29.5$ $\mathrm{g} / \mathrm{L}$ ) produces a quite high mortality level for the gold-mouth turban larvae. The increased temperature to $3^{\circ} \mathrm{C}$ from the average annual temperature can decrease the larval survival rate by $25 \%$ (Conaco \& Cabaitan, 2020). The similar condition was reported by Xue et al. (2010), that the temperature and salinity interactions had a significant influence in the increased daily body weight and shell length of $B$. areolata, although the survival rate was relatively low at the highest temperature. The low SR in the extreme temperature and salinity conditions was thought to cause ineffective metabolism and extracellular fluidic osmoregulation processes (Winanto et al., 2009). Salinity impacts on the survival rate value. However, a lower temperature tends to increase the salinity tolerance. In contrast, a higher temperature tends to cause more energy loss and decrease the disease resistance for larvae, which implicates on the mass pathogenic bacterial distribution ( $\mathrm{Lu}$ et al., 2016). Montory et al. (2016) reported that the C. peruviana veliger larvae maintained at about 6 hours in low salinity level obtained high mortality level in the juvenile stage.

The highest specific growth rate at $27^{\circ} \mathrm{C} \pm 0.5$ (A1) temperature was found in the B3 treatment with a significant different value from the B2 treatment. This condition means that the salinity range of 31.5-35.5 $\mathrm{g} / \mathrm{L}$ improves the larval specific growth rate until the 20 day old juvenile. Meanwhile at $30^{\circ} \mathrm{C} \pm 0.5$ (A2) temperature, the B3 treatment also showed the highest performance, but showing insignificant difference 
value to other treatments. This condition was almost similar to the hybrid abalone larvae that obtained the optimum growth and development at 30-36 g/L salinity and T. niloticus at 30-35 g/L salinity (Dolorosa et al., 2013; Amin et al., 2016). Apines-Amar et al. (2020) stated that the green mussle (Perna viridis) larvae from the initial to pediveliger stadia obtained the highest growth rate at $29-30^{\circ} \mathrm{C}$ temperature and $30-33 \mathrm{~g} / \mathrm{L}$ salinity.

The lowest specific growth rate at $27^{\circ} \mathrm{C} \pm 0.5$ (A1) temperature was found in the B1 treatment and showed a significant different value form other treatments. This condition indicates that the larval growth to 20 day old juvenile tends to be optimum in high and low salinity levels (28.5-29.5 $\mathrm{g} / \mathrm{L})$. This condition can inhibit the larval specific growth rate to 20 days old juvenile. Meanwhile at $30^{\circ} \mathrm{C} \pm 0.5$ (A2) temperature, the $\mathrm{B} 1$ treatment also showed the lowest percentage and insignificant different value to the B2 treatment. The low larval specific growth rate at low salinity level was thought to be associated with the energy sharing process (Amin et al., 2016) and biomineralization process that implicates on the shell formation. As reported by Bashevkin and Pechenik (2015), the interaction of salinity and low temperature can cause the decreased anorganic level percentage in the snail C. fornicata larvae. Ivanin et al. (2013) also explained that the increased temperature caused more energy loss for osmoregulatiotn than for the protein synthesis, resulting in the decreased glycogen storage and protein level in the tissue. Low salinity causes the lowest feed consumption rate and implicates on lower shell growth rate (Montory et al., 2014).

The water quality parameters obtained during the experimental period were almost similar to the gold-mouth turban habitat condition in the Pelabuhan Ratu water area, namely, $\mathrm{pH}$ 7-8, 3-5 mg/L DO, 0.092-0.656 mg/L nitrate, and 0.001-0.029 mg/L nitrite (Soekendarsi, 2018). In addition to affecting the biota, the water quality parameters also play an important role to support the live feed growth (Navicula sp.). The optimum concentrations of $\mathrm{NO}_{3}{ }^{-}$and $\mathrm{PO}_{4}{ }^{3-}$ for Navicula sp. growth are $3.6 \mathrm{mg} / \mathrm{L}$ and $0.18 \mathrm{mg} / \mathrm{L}$ (Xiaobo et al., 2014). Amalah et al. (2018) stated that the Navicula sp. density is closely affected by the $\mathrm{N}$ and $\mathrm{P}$ availabilities in the culture media. Microalgae require phosphate at 0.018-0.09 $\mathrm{mg} / \mathrm{L}$ concentration with the maximum level of 8.90-17.80 mg/L. Moreover, Yang et al. (2014) stated that the $\mathrm{N}$ and $\mathrm{P}$ ranges for the optimum diatom growth are 12.36-74.16 mg/L and 1.70$3.98 \mathrm{mg} / \mathrm{L}$, respectively.

\section{CONCLUSION}

Salinity has a greater effect than temperature to support the larval growth. Nevertheless, temperature and salinity are important to support the stadia developments, attachment capability, and survival rate of gold-mouth turban larvae. The optimum temperature and salinity ranges for maintaining the gold-mouth turban are 26.5$27.5^{\circ} \mathrm{C}$ and $31.5-35.5 \mathrm{~g} / \mathrm{L}$, respectively.

\section{ACKNOWLEDGMENT}

Authors would like to thank the Indonesian Ministry of Research, Technology, and Higher Education for funding this work and Central Marine Bio Industry, Indonesian Institute of Sciences (LIPI) Mataram for facilitating and supporting this work.

\section{REFERENCES}

Amalah N, Widyartini DS, Christiani, Hidayah HP. 2018. The effect of dilution level of liquid tapioca waste culture medium and concentration of phosphate on the growth of microalgae Navicula sp. Nusantara Bioscience 10: 65-69.

Amin A, Yusnaini, Effendy IJ. 2016. Effects of different salinity levels on the metamorphosis development and growth of hybrid abalone larvae to early juvenile 35-day old. Media Akuatika 1: 197-206.

Apines-Amar MJS, Rendaje DC, Pinosa LAG, Laureta LVJ, Masculino AND, Pedroso FL, Mero FFC, Capaque TPV, Cadangin JF. 2020. Effects of water quality, stocking density, water exchange frequency, and food, on growth and survival of the green mussel, Perna viridis larvae. The Israeli Journal of Aquaculture 72: $1-12$.

Banne TSP, Yusnaini, Effendy IJ. 2017. The quality of abalone egg Haliotis asinina which given by different feeds. Media Akuatika 2: 446-457.

Bashevkin SM, Pechenik JA. 2015. The interactive influence of temperature and salinity on larval and juvenile growth in the gastropod Crepidula fornicata (L.). Journal of Experimental Marine Biology and Ecology 470: 78-91.

Conaco C, Cabaitan PC. 2020. Influence of salinity and temperature on the survival and settlement of Heliopora coerulea larvae. Marine Pollution Bulletin 150: 7110703. 
Dolorosa RG, Grant A, Gill JA, Avillanosa AL, Gonzales BJ. 2013. Indoor and deep sub-tidal intermediate culture of Trochus niloticus for restocking. Reviews in Fisheries Science 21: 414-423.

Hamzah AS, Hamzah M, Hamzah MS. 2016a. Development and survival rate of the pearl oyster Pinctada maxima larvae in different temperature conditions. Media Akuatika 1: 152-160.

Hamzah MS, Endang YH, Marsoedi, Fadjar M. 2016b. Protease enzyme reactability effect of pearl oyster Pinctada maxima flesh shell growth at different water temperature and salinity. International Journal of Biosciences 9: 124-137.

Hamzah MS. 2015. Survival and seedling growth of moon-eyed snail Turbo chrysostumus L. on different temperature conditions. Jurnal Ilmu dan Teknologi Kelautan Tropis 7: 299-308.

Huo ZM, Guan HW, Rbbani MG, Xiao YX, Zhang XK, Fan C, Yan XW. 2017. Effects of environmental factors on growth, survival, and metamorphosis of geoduck clam Panopea japonica A. Adams, 1850 larvae. Aquaculture Reports 8: 31-38.

Ivanina AV, Dickinson GH, MatooOB, BagweR, DickinsonA, Beniash E, Sokolova IM. 2013. Interactive effects of elevated temperature and $\mathrm{CO}_{2}$ levels on energy metabolism and biomineralization of marine bivalves Crassostrea virginica and Mercenaria mercenaria. Comparative Biochemistry and Physiology Part A: Molecular and Integrative Physiology 166: 101-111.

Kimani EN. 1996. The larval development and juvenile growth of the silver mouth turban, Turbo argyrostomus. [Thesis]. Okinawa: University of The Ryukyus.

Ko GWK, Dineshram R, Campanati C, Chan VBS, Havenhand J, Thiyagarajan V. 2014. Interactive effects of ocean acidification, elevated temperature, and reduced salinity on early-life stages of the Pacific Oyster. Environmental Science and Technology 48: 10079-10088.

Kono N, Yamakawa H. 2002. Comparison of larval shell morphology of two coastal turbinid snails, Turbo (Batillus) cornutus and Turbo (Marmarostoma) stenogyrus (Vetigastropoda: Turbinidae). Bulletin of Fisheries Research Agency 4: 19-24.

Lah RA, Smith J, Savins D, Dowell A, Bucher D, Benkendorff K. 2016. Investigation of nutritional properties of three species of marine turban snails for human consumption. Food Science and Nutrition 5: 14-30.

Lu W, Shen M, Fu J, Li W, You W, Ke C. 2016. Combined effects of temperature, salinity and rearing density on growth and survival of juvenile ivory shell, Babylonia areolata (Link 1807) population in Thailand. Aquaculture Research 48: 1-8.

Manuel AV, Tu PTC, Tsutsui N, Yoshimatsu T. 2019. Effect of salinity change and exposure time on the egg stages of two abalone species Haliotis discus discus and H. gigantea. Fisheries Science 86: 27-33.

Mccormick TB, Navas G, Buckley LM, Biggs C. 2016. Effect of temperature, diet, light, and cultivation density on growth and survival of larval and juvenile white abalone Haliotis sorenseni (Bartsch, 1940). Journal of Shellfish Research 35: 981-992.

Montory JA, Chaparro OR, Navarro JM, Pechenik JA, Cubillos VM. 2016. Post-metamorphic impact of brief hyposaline stress on recently hatched veligers of the gastropod Crepipatella peruviana (Calyptraeidae). Marine Biology 163: 1-7.

Montory JA, Chaparro OR, Pechenik JA, Diederich CM, Cubillos VM. 2014. Impact of short-term salinity stress on larval development of the marine gastropod Crepipatella fecunda (Calyptraeidae). Journal of Experimental Marine Biology and Ecology 458: 39-45.

Morash AJ, Alter K. 2015. Effects of environmental and farm stress on abalone physiology: perspectives for abalone aquaculture in the faceof global climate change. Reviews in Aquaculture 7: 1-27.

Mukhlis A, Abidin Z, Rahman I. 2017. Pengaruh konsentrasi pupuk ammonium sulfat terhadap pertumbuhan populasi sel Nannochloropsis sp. BioWallacea: Jurnal Ilmiah Ilmu Biologi 3: 149-155.

Noble WJ, Benkendorff K, Harris JO. 2015. Growth, settlement and survival of Dicathais orbita (Neogastropoda, Mollusca) larvae in response to temperature, diet and settlement cues. Aquaculture Research 46: 1455-1468.

Nowland SJ, O'Connor WA, Penny SS, Osborne MWJ, Southgate PC. 2019. Water temperature and salinity synergistically affect embryonic and larval development of the tropical black-lip rock oyster Saccostrea echinata. Aquaculture International 27: 1239-1250.

Peck LS, Heiser S, Clark MS. 2016. Very slow 
embryonic and larval development in the Antarctic limpet Nacella polaris. Polar Biology 39: 2273-2280.

Rico-Villa B, Pouvreau S, Robert R. 2009. Influence of food density and temperature on ingestion, growth and settlement of Pacific oyster larvae, Crassostrea gigas. Aquaculture 287: 395-401.

Rippington A. 2015. Effects of temperature, salinity and food stress on larval growth and development inthe Olympia oyster, Ostrea lurida. [Thesis]. Columbia: University of Victoria.

Ruf M. 2007. Gastropod biodiversity in the waters of Sabah (Malaysian Borneo). Tentacle 15: 23-25.

Sayco SLG, Conaco C, Neo ML, Cabaitan PC. 2019. Reduced salinities negatively impact fertilization success and early larval development of the giant clam Tridacna gigas (Cardiidae: Tridacninae). Journal of Experimental Marine Biology and Ecology 516: 35-43.

Seinor KM, Smith SDA, Logan M, Purcell SW. 2020. Biophysical habitat features explain colonization and size distribution of introduced Trochus (Gastropoda). Frontiers in Marine Science 7: 223.

Setyono DED, Kusuma HA, Badi BF. 2013. Pemijahan siput mata bulan Turbo chrysostomus (Linnaeus, 1758). Oseana 38: $1-8$.

Soekendarsi E. 2018. The habitat of yellow mouth turban Turbo chrysostomus, Linnaeus, 1758. Journal of Physics: Conference Series 979 012040.

Tao W, Qi L. 2018. Effects of salinity and temperature on growth and survival of juvenile iwagaki oyster Crassostrea nippona. Journal of Ocean University of China 17: 1-6.

Ubaidillah R, Marworo RM, Kadiaty RK, Fahmi, Wowor D, Mumpuni, Pratiwi R, Tjakrawidjaja AH, Mudjiono, Hartati ST, Heryanto, Riyanto A, Mujiono N. 2013. Biota perairan terancam punah di Indonesia (prioritas perlindungan). Direktorat Konservasi Kawasan dan Jenis Ikan Ditjen Kelautan, Pesisir, dan PulauPulau Kecil Kementerian Kelautan dan Perikanan Bekerjasama dengan Lembaga Ilmu Pengetahuan Indonesia. 257 hal.
Winanto T, Soedharma D, Affandi R, Sanusi HS. 2009. The effect of temperature and salinity to the physiological respons on the larvae of Pinctada maxima (Jameson). Jurnal Biologi Indonesia 6: 51-69.

Xiaobo Z, Shaojun P, Feng L, Tifeng S, Jing L. 2014. Biological identification and determination of optimum growth conditions for four species of Navicula. Acta Oceanologica Sinica 33: 111-118.

Xue M, Ke C, Wang D, Wei Y, Xu Y. 2010. The combined effects of temperature and salinity on growth and survival of hatcheryreared juvenile spotted babylon, Babylonia areolata (Link 1807). Journal of The World Aquaculture Society 41: 116-122.

Yang M, Zhao W, Xie X. 2014. Effects of nitrogen, phosphorus, iron and silicon on growth of five species of marine benthic diatoms. Acta Ecologica Sinica 34: 311-319.

Yang W, Huan P, Liu B. 2020. Early shell field morphogenesis of apatellogastropod mollusk predominantlyrelies on cell movement and F-actindynamics. BMC Developmental Biology 20: 1-10.

Yu Z, Yang M, Song $\mathrm{H}$, Hu Z, Zhou C, Wang X, Li H, Zhang T. 2020. Settlement and metamorphosis of Rapana venosa (Gastropoda: Muricidae) with implications for artificial culture. Journal of Oceanology and Limnology 38: 249-259.

Zamora LN, Delorme NJ, Byrne M, Sewell MA. 2020. Lipid and protein utilization during lecithotrophic development in the asteroid Stegnaster inflatus, with a review of larval provisioning in lecithotrophic echinoderms. Marine Ecology Progress Series 641:123-134.

Zhang T, Song H, Bai YC, Sun YC, Zhang XF, Ban SJ, Yu ZL, Yang MJ, Wang HY.2017. Effects of temperature, salinity, diet and stocking density on development of the veined Rapa whelk, Rapana venosa (Valenciennes, 1846) larvae. Aquaculture International 25: 1577-1590.

Zupo V, Patti FP. 2009. Laboratory spawning, larval development and metamorphosis of the marine snail Nassarius reticulatus (L.) (Caenogastropoda, Nassariidae). Invertebrate Reproduction dan Development 53: 23-31. 